\title{
A avaliação da avaliação
}

\author{
A universidade morre sem avaliação, mas apenas adia a sua morte \\ se não avaliar a avaliação.
}

\author{
Cristovam Buarque, ACS - Assessoria de Comunicação Social do Ministério da Educação
}

A gente só não avalia aquilo que despreza. O que não amamos é avaliado com rigor e rancor; o que amamos é avaliado com rigor e carinho, mas é avaliado também.

Um dos avanços no ensino superior brasileiro, nos últimos anos, foi a aceitação de uma cultura da avaliação. E não deve ser suspensa.

Deve continuar ainda com mais rigor que é preciso ampliá-la, avaliar também o desempenho dos ministros e de todo o pessoal envolvido na atividade universitária. Ainda mais, é preciso tanto rigor com a avaliação, que temos de avaliar, constantemente, a própria avaliação, seus métodos e seus indicadores. E não ficar passivamente olhando os resultados. Deve fazer parte da avaliação sua análise e suas conseqüências em políticas que se proponham a corrigir o que está errado. Um relatório de avaliação está incompleto se ele não vem acompanhado de propostas. A avaliação é um meio, não o propósito.

Esta é a diferença entre prova e avaliação. A primeira mede apenas o que resultou de ações no passado; a segunda serve de base para mudanças no futuro.

A idéia e a prática da avaliação universitária são antigas. O importante papel do ex-ministro Paulo Renato foi empenhar-se e conseguir ampliá-la a todo o País, criando a cultura da avaliação. Outro mérito seu foi avaliar as avaliações anteriores e modificá-las. Em 1986, o então reitor da Universidade de Brasília criou um órgão de avaliação e implementou um sistema de avaliação que tinha o propósito radical de fazer "auditoria acadêmica", como foi dito na época "se a universidade faz auditoria financeira, ainda mais importante é fazer sua auditoria acadêmica”. Mas aquele sistema era insuficiente, porque não usava critérios usados pelo atual Exame Nacional de Cursos, o Provão, para medir o aprendizado dos alunos. O ministro Paulo Renato tem o mérito de ter incorporado a avaliação dos alunos como parte do processo de avaliação das universidades.

Da mesma forma, é preciso levar adiante o que já foi feito, sem o conservadorismo de achar que a avaliação é perfeita. Toda avaliação é imperfeita e incompleta e deve ser avaliada, modificada e ampliada. Ninguém defende seriamente a avaliação das universidades se não defender a constante avaliação dos métodos de avaliação. Ou se critica as mudanças antes de conhecê-las. É a falta de avaliação que cria as ortodoxias que amarram o pensamento e destrói a criatividade. Por isso os ortodoxos têm pavor à avaliação. O medo de avaliar a avaliação, a ortodoxia em métodos antigos de avaliação, é uma forma também de aprisionar o pensamento, frear a criatividade, impedir o surgimento do novo.

A universidade morre sem avaliação, mas apenas adia sua morte se não avaliar a avaliação. A universidade de hoje está dividida entre os que têm o pavor às avaliações e aqueles que têm pavor à avaliação da avaliação. Ambos são ortodoxos inimigos do avanço do conhecimento e da construção de uma nova universidade, dinâmica, eficiente, criativa e comprometida. Vanguardista na criação do pensamento no mundo global e vanguardista na construção de uma realidade brasileira e mundial sem exclusão social.

O atual Ministério da Educação vai manter a cultura da avaliação tão radicalmente, que vai avaliar tudo, inclusive o ministro e também os métodos de avaliação.

E vai avaliar sem parar a atual avaliação. O Provão de 2003 já está em andamento e não será interrompido. Serão acrescentadas novas questões, novos aspectos e, sobretudo ele será divulgado contendo políticas alternativas para corrigir as falhas que ele mostrar no sistema do ensino superior brasileiro. Vai incorporar mudanças para melhor, mais rigor e mais amplitude, se houver tempo.

Com todo seu mérito, o Provão é insuficiente: mede apenas o aprendizado do aluno em sua área específica do conhecimento, não considera outros aspectos fundamentais do processo universitário, não avalia as administrações das universidades, nem o papel dos governos através do Ministério da Edu- 
cação e outros órgãos. Uma avaliação completa tem que considerar a universidade como um processo que vai muito além do aprendizado de cada aluno na sala de aula, tem que levar em conta o desempenho de cada um dos atores da universidade. E tem que servir de base para ações posteriores de cada um deles.

Artigo publicado na Agência Brasil em 25/05/2003

\title{
Proponha, discuta, participe! Filie-se à ABENO.
}

\section{A Associação Brasileira de Ensino Odontológico tem como OBJETIVOS:}

- Congregar todas as instituições de ensino odontológico no Brasil

- Atuar objetivando a melhoria do ensino odontológico no País

- Adotar medidas que objetivem a formação e o aperfeiçoamento do pessoal docente e dos profissionais de Odontologia

- Estimular as atividades de pesquisa na ciência odontológica

- Incentivar as atividades de extensão e de educação em saúde junto às comunidades

- Defender os interesses das instituições de ensino que a integram

- Constituir-se fator de integração entre o ensino e a cultura nacional

- Manter relações com as entidades representativas da categoria odontológica

- Manter intercâmbio com entidades estrangeiras representativas da docência odontológica

\author{
Filiando-se à ABENO você \\ estará inserido no processo de \\ melhoria do ensino e do \\ exercício da Odontologia \\ no Brasil.
}

